\title{
Books Received / Livres reçus
}

Argent, Alan. The Richard Baxter Treatises: A Catalogue and Guide. Rochester, NY: Boydell Press, 2018. Pp. xii, 280. ISBN 978-1-78327-292-1 (hardcover) US\$225.

Arnold, Matthieu. Les femmes dans la correspondance de Luther. Études d'histoire et de philosophie religieuses, 87. Paris : Classiques Garnier, 2017. 154 p. ISBN 978-2-406-06996-6 (broché) $29 €$.

Bassnett, Madeline. Women, Food Exchange, and Governance in Early Modern England. Early Modern Literature in History. New York: Palgrave Macmillan, 2016. Pp. ix, 248. ISBN 978-3-319-40867-5 (hardcover) $€ 88.39$.

Capodieci, Luisa, Estelle Leutrat, Rebecca Zorach, éds., avec la collaboration de Youenn Morvan. Miroirs de Charles IX. Travaux d'Humanisme et Renaissance, 584. Genève: Droz, 2018. 284 p. + 73 figs. ISBN 978-2-60005801-8 (broché) 48.99 CHF.

Cavendish, Margaret. Poems and Fancies with The Animal Parliament. Edited by Brandie R. Siegfried. The Other Voice in Early Modern Europe: The Toronto Series 64 / Medieval and Renaissance Texts and Studies 536. Toronto: Iter Press / Tempe: Arizona Center for Medieval and Renaissance Studies, 2018. Pp. xx, $462+11$ ill. ISBN 978-0-86698-593-2 (paperback) US\$59.95.

Colahan, Clark, Jagoda Marszalek, and Pedro Manuel Suárez-Martínez, eds. El Colloquium elegans de Bernal Díaz de Luco. Tradición senequista, eclesiástica y picaresca. Noctes Neolatinae, Neo-Latin Texts and Studies 31. Hildesheim: Georg Olms Verlag, 2018. Pp. x, 294. ISBN 978-3-48715663-7 (paperback) €58.

Costa, Margherita. The Buffoons, A Ridiculous Comedy: A Bilingual Edition. Edited and translated by Sara E. Díaz and Jessica Goethals. The Other Voice in Early Modern Europe: The Toronto Series 63 / Medieval and Renaissance Texts and Studies 535. Toronto: Iter Press / Tempe: Arizona Center for Medieval and Renaissance Studies, 2018. Pp. xv, $368+9$ ill. ISBN 978-0-86698-592-5 (paperback) US\$54.95.

Du Bellay, Jean. Correspondance du cardinal Jean Du Bellay, Tome VI: 15501555, publié par Rémy Scheurer, Loris Petris, David Amhert et Nathalie Guillod-Falconet, avec la collaboration de Ruth Stawarz-Luginbuhl. Paris: 
Société de l'Historie de France / Éditions de Boccard, 2015. 523p. ISBN 978-2-35407-140-0 (relié) $45 €$.

Du Bellay, Jean. Correspondance du cardinal Jean Du Bellay, Tome VII : 15551559, publié par Rémy Scheurer, Loris Petris, David Amhert et Nathalie Guillod-Falconet, avec la colaboration de Ruth Stawarz-Luginbuhl. Paris: Société de l'Historie de France / Éditions de Boccard, 2017. 574 p. ISBN 978-2-35407-145-5 (relié) $60 €$.

Erasmus, Desiderius. The Correspondence of Erasmus: Letters 2472 to 2634, April 1531-March 1532. Translated by Charles Fantazzi, annotated by James M. Estes. Collected Works of Erasmus 18. Toronto: University of Toronto Press, 2018. Pp. xx, $422+10$ ill., 1 map. ISBN 978-1-4875-0199-0 (hardcover) \$200.

Fell, Margaret. Women's Speaking Justified and Other Pamphlets. Edited by Jane Donawerth and Rebecca M. Lush. The Other Voice in Early Modern Europe: The Toronto Series 65 / Medieval and Renaissance Texts and Studies Series 538. Toronto: Iter Press / Tempe: Arizona Center for Medieval and Renaissance Studies, 2018. Pp. xx, $223+4$ ill. ISBN 978-086698-595-6 (paperback) US\$39.95.

Gáldy, Andrea M. The Art, History and Architecture of Florentine Churches.

Newcastle upon Tyne: Cambridge Scholars Publishing, 2016. Pp. xxix,

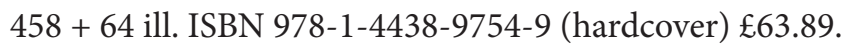

Goodblatt, Chanita. Jewish and Christian Voices in English Reformation Biblical Drama: Enacting Family and Monarchy. Routledge Studies in Renaissance Literature and Culture. London: Routledge, 2017. Pp. xi, $256+15$ figs., 3 tables. ISBN 978-1-4724-7978-5 (hardcover) \$140.

Habinek, Lianne. The Subtle Knot: Early Modern English Literature and the Birth of Neuroscience. Montreal and Kingston: McGill-Queen's University Press, 2018. Pp. xi, $283+39$ ill. ISBN 978-0-7735-5318-7 (hardcover) $\$ 49.95$.

Higginbotham, Jennifer, and Mark Albert Johnston, eds. Queering Childhood in Early Modern English Drama and Culture. London: Palgrave, 2018. Pp. x, $281+3$ ill. ISBN 978-3-319-72768-4 (hardcover) \$109.

Hogan, Sarah. Other Englands: Utopia, Capital, and Empire in an Age of Transition. Stanford: Stanford University Press, 2018. Pp. x, 256. ISBN 978-1-5036-0516-9 (hardcover) US\$60. 
Jungić, Josephine. Giuliano de' Medici: Machiavelli's Prince in Life and Art. Edited and revised by Anne Leader. Montreal and Kingston: McGillQueen's University Press, 2018. Pp. xi, $298+40$ colour ill. ISBN 978-07735-5320-0 (hardcover) \$49.95.

Katz, Dana E. The Jewish Ghetto and the Visual Imagination of Early Modern Venice. Cambridge: Cambridge University Press, 2017. Pp. xiii, 188. ISBN 978-1-107-16514-4 (hardcover) £75.

Kennedy, William J. Petrarchism at Work: Contextual Economies in the Age of Shakespeare. Ithaca: Cornell University Press, 2016. Pp. xi, 333. ISBN 9781-5017-0001-9 (hardcover) US\$82.50.

Kenny, Neil, ed. Text, Knowledge and Wonder in Early Modern France: Studies in Honour of Stephen Bamforth. Special issue of Nottingham French Studies 56.3 (2017): 249-368.

Kuzner, James. Shakespeare as a Way of Life: Skeptical Practice and the Politics of Weakness. New York: Fordham University Press, 2016. Pp. 232. ISBN 978-0-8232-6993-8 (hardcover) US $\$ 85$.

Lemon, Rebecca. Addiction and Devotion in Early Modern England. Philadelphia: University of Pennsylvania Press, 2018. Pp. xv, 258. ISBN 978-0-8122-4996-5 (hardcover) US\$65.

Martínez, Alberto A. Burned Alive: Giordano Bruno, Galileo and the Inquisition.

London: Reaktion Books, 2018. Pp. $348+21$ ill. ISBN 978-1-78023-896-8 (hardcover) US $\$ 40$.

Milligan, Gerry. Moral Combat: Women, Gender, and War in Italian Renaissance Literature. Toronto: University of Toronto Press, 2018. Pp. xi, $332+3$ ill. ISBN 978-1-4875-0314-7 (hardcover) \$75.

Montfort, Marie-Laure. Janus Cornarius et la redécouverte d'Hippocrate à la Renaissance. Textes de Janus Cornarius édités et traduits. Bibliographie des éditions Cornariennes. Turnhout: Brepols, 2017. 513 p. + 6 ill. ISBN 9782-503-53803-7 (relié) $85 €$.

O'Connor, Michael. Cajetan's Biblical Commentaries: Motive and Method. St Andrews Studies in Reformation History. Leiden: Brill, 2017. Pp. xvi, 302. ISBN 978-90-04-32506-7 (hardcover) €134.

Parker, Patricia. Shakespearean Intersections: Language, Contexts, Critical Keywords. Philadelphia: University of Pennsylvania Press, 2018. Pp. 409 + 12 ill. ISBN 978-0-8122-4974-3 (hardcover) US\$59.95. 
Racz, G.J., trans. and Barbara Fuchs, ed. The Golden Age of Spanish Drama. A Norton Critical Edition. New York: W.W. Norton \& Company, 2018. Pp. xxii, 612. ISBN 978-0-393-92362-9 (paperback) US\$15.

Rhodes, Neil. Common: The Development of Literary Culture in SixteenthCentury England. Oxford: Oxford University Press, 2018. Pp. xiii, 345. ISBN 978-0-1987-0410-2 (hardcover) US\$74.

Suthor, Nicola. Rembrandt's Roughness. Princeton: Princeton University Press, 2018. Pp. $240+25$ colour, 57 b/w ill. ISBN 978-0-691-17244-6 (hardcover) US\$60.

Thiroux d'Arconville, Marie-Geneviève-Charlotte. Selected Philosophical, Scientific, and Autobiographical Writings. Edited and translated by Julie Candler Hayes. The Other Voice in Early Modern Europe: The Toronto Series 58 / Medieval and Renaissance Texts and Studies Series 522. Toronto: Iter Press / Tempe: Arizona Center for Medieval and Renaissance Studies, 2018. Pp. xv, 243. ISBN 978-0-86698-578-9 (paperback) US $\$ 44.95$.

Tommasino, Pier Mattia. The Venetian Quar'an: A Renaissance Companion to Islam. Translated by Sylvia Notini. Philadelphia: University of Pennsylvania Press, 2018. Pp. xix, $297+1$ ill. ISBN 978-08122-5012-1 (hardcover) US\$59.95.

Williams, Robert. Raphael and the Redefinition of Art in Renaissance Italy. Cambridge: Cambridge University Press, 2017. Pp. xi, $304+113$ ill. ISBN 978-1-3164-6003-0 (hardcover) US\$114.95.

Wolk-Simon, Linda, ed. The Holy Name: Art of the Gesù: Bernini and His Age. With the collaboration of Christopher M.S. Johns. Early Modern Catholicism and the Visual Arts 17. Philadelphia: Saint Joseph's University Press, 2018. Pp. xv, $639+246$ colour ill. ISBN 978-0-91610100-8 (hardcover) US $\$ 50$.

Zarri, Gabriella. Figure di donne in età moderna. Modelli e storie. Storia e letteratura, Raccolta di studi e testi 298. Rome: Edizioni di storia e letteratura, 2017. Pp. xvi, 276. ISBN 978-8-8637-2995-5 (paperback) €38. 